\title{
Level of Bus Performance Based On the Relationship Between Distance and Travel Time of Universiti Tun Hussein Onn Malaysia (UTHM) Bus Services
}

\author{
Joewono Prasetijo ${ }^{1, a}$, Wan Zahidah Musa ${ }^{1}$, Zaffan Farhana Zainal ${ }^{1}$, Kamarudin Ambak ${ }^{1}$ and Mohd Erwan Sanik \\ ${ }^{1}$ Smart Driving Research Center (SDRC), Universiti Tun Hussein Onn Malaysia, 86400 Parit Raja, Batu Pahat, Johor
}

\begin{abstract}
UTHM bus service is an important transport mode for most students at Universiti Tun Hussein Onn because it such primary public vehicle to support students movements around the campus, within and outside student apartments. This service is often associated with the quality of service in terms of time, stops and comforts. Therefore, this following study is focused on investigation on several UTHM bas routes which was based on bas operations such as distance and travel time/travel distance that would determine the level of service provided. Primary data were collected mainly to obtain information relate to speed, bas position, time movement/circulations of bus and time headway. These were obtained by installing GPS-Slute Gear i-trail along bus travels. In addition, additional data were collected by exploring previous studies regarding to the bus services such as Highway Capacity Manual (HCM 2010). The approach used was based on assessment of progress used to determine the level of quest service and such obstacle frequently occurs with results on bus delays, volume of unequal that can be overcome according to the assessments that have been provided.
\end{abstract}

\section{Introduction}

Bus is one of the most important transport modes and contributes some aspects in daily life. The mode would be an alternative for users to travel [1]. Generally bus would be use for public transport services instead of use private vehicles or other public transports/modes such as taxis, carpooling or chartered bus, which is not for sharing [2]. Furthermore, most public transport is on the way of progressing on punctuality with service scheduled for the user's convenience.

Public transport system in universities is often used for the purpose to facilitate the students/staff movement from one place to another within and out of the campus. The Office of Academic Management (PPA) Universiti Tun Hussein Onn Malaysia (UTHM) provides UTHM bus service [3]. Therefore, bus quality services must be emphasized on comfort and safe for all students/university members, especially for students who stay in the residential colleges and they do not have private vehicles. In addition, the bus functioned as transport services to transfer students from a class to another, from lecture hall to other destinations (halls, class or café). Therefore, these movements of buses would show the level of bus service surrounding university area in term of speed, time travel, passenger taking and alighting from bus, and the impact of stops. The following study shows how the level of bus services

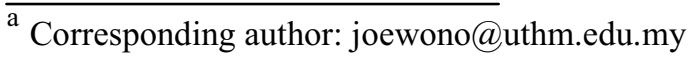

can be measured and the quality of services can be predicted [4].

\section{Literature Review}

\subsection{Characteristic Transport Services}

One of the process stages of determining the network selection and option in the perception of transport services/quality is based on an assessment of each option in the nature of services related to the transport modes. Characteristics of transport services (when/time, where/place, why, type of modes and the route) would affect on the results of the tendency of transport users to travel. Therefore, all transport services should be well considered [5].

\subsubsection{Travel Time}

Generally, travel time is defined as the time taken to complete the journey. As speed increases, the travel time required to reach the destination which also decreases and vice versa. Therefore, time travel is inversely proportional to the speed. It usually measured by the average local time and distance [6]. Referring to the User Guide of Public Transportation (2012), journey times for the local road to the bus stop; a must not be more than 30 
minutes in one trip and the following figure 1 shows its characteristics [2].

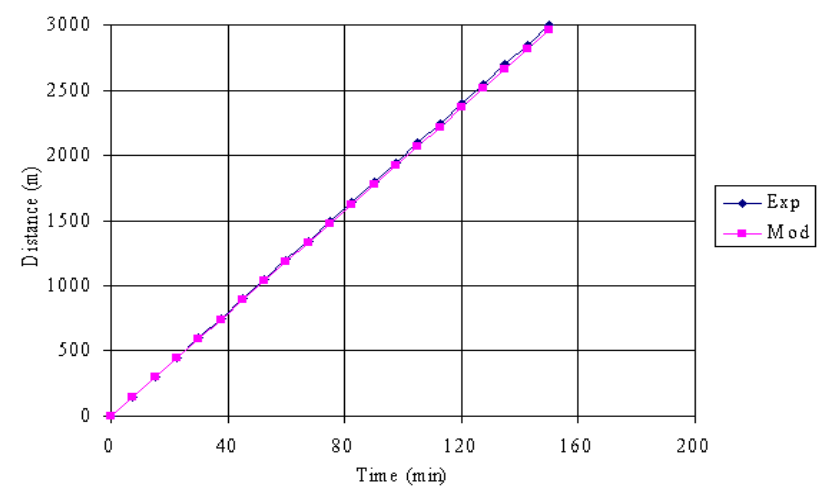

Figure 1. Graph plotted show the distance vs time is vice versa

\subsubsection{Time Headway}

It is considered that vehicles microscopic characterization related to volume is the advancement of time or just progress. Generally, headways/progress of time is defined as the time difference between any two consecutive vehicles when they cross a point. In practice, it involves in measuring the time between the passages of the rearbumper that passes a given point. Normally, headways for the convenience of public transport bus design gap would be between 5 to 20 minutes.

\subsubsection{Headway Distance}

Another relevant parameter is the distance progress (space). It is defined as the distance between the same two consecutive vehicles at any time. It involves the measurement of the distance measured from the rearbumper to the rear-bumper of the successive vehicles pass at a point within time interval. It is also known as the 'spacing'. The following figure 2 shows the concept of progress/headways.

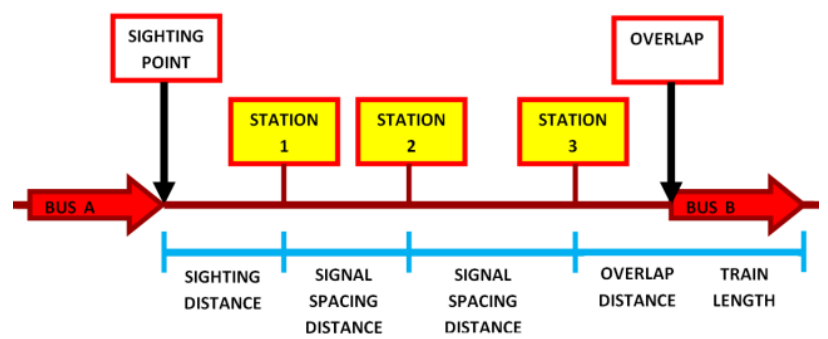

Figure 2. Concept of headway distance

\subsubsection{Trip Chaining}

Travel chain can be defined as bus travelling through an area from a stop to others, which every stop has been defined. Chaining travel is often used to change the direction of bus travelling as a result of bus route changes through certain area. It also provide a huge influence towards a bus journey times and quality of the services.

\subsubsection{The Period Used In the Course (Time Travel)}

Regardless of passenger income and mode of transit, all individual eventually faces the same problem in as 24 hours a day of traffic operations. There was the time spent in which is mainly focused on affects the scheduling of buses and it closely related to the travel distance and travel speed used while transit travelling from one destination to another. There is in common that the amount of time travel of vehicle used by different modes; the time spent of each vehicle per day is constant in average.

\subsubsection{Rates of Excessive Waiting Period}

Excessive waiting time is defines as the difference between the scheduled time of arrival and the actual to the bus arrived in such interval/section of road divided by the number of observations. Early arrival without departing early is not counted and assumed as time errors. However, travel at the normal departure time with the early arrival would be counted as "excessive' for the purpose of calculating the average exceeds waiting time. Rate of excessive waiting times are excessive waiting time (in minutes) divided by the mean length of bus passengers while travelling route (s) in section of the road.

\subsubsection{Rates of Stop Time at the Bus Stops (Dwell Time)}

Stop time is the time that the bus stop and the measuring instrument are in seconds. This includes the time for the bus to stop, time of opening and closing the door of the bus, the time for passenger to entrance and exit at the bus stop before further bus movements.

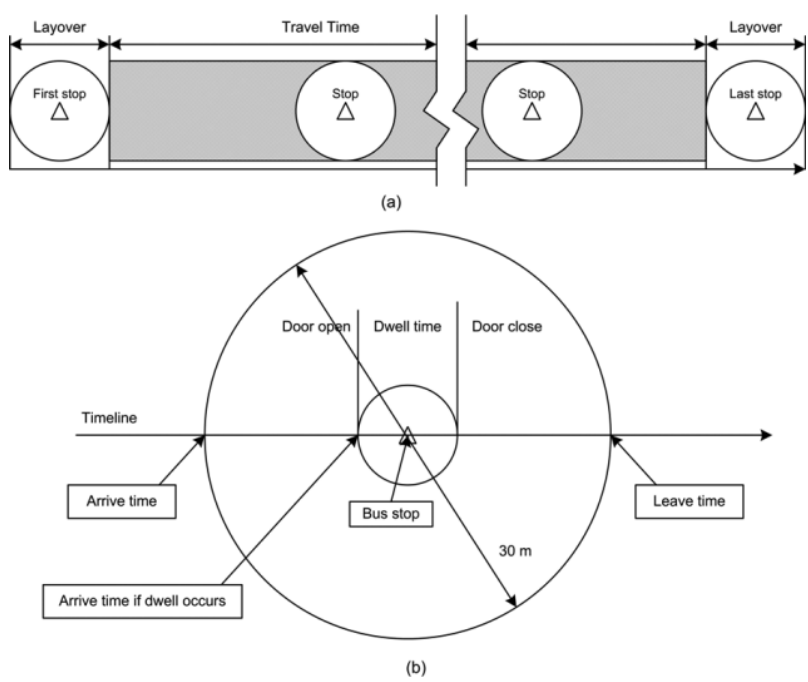

Figure 3. Rate of bus stop at the station (Sunif F., 2011)

\section{Materials and Methods}

To conduct the current study and observing the data, authors have chosen the common method of observations 
by using data logger, (four) 4 digits tally counter and a stopwatch, which is considered more simple and easier to control and monitor. Data logger is the device that easy to use, it is placed in the bus during the study/data collection and data recording; speed, bus positions/the bus stops which are shown in longitude and latitude coordinates as well as the time of bus stopped. Furthermore, there was also considered more accurate and easily operated data. The stopwatch is simply used to measure time (headway) of a bus through the interval/sections of road. In addition, 4-digit tally counter data are used to observe the distribution of students/passenger on boarding and alighting.

Further data collection on bus velocity and distance is to use data logger, 4-digits tally counter and stopwatch with following steps; selecting buses, no bus parking and bus must be stop at the shelter/bus stops. Data was generated in accordance to the sections selected. Bus stops were selected that may represent the high number passengers.

Excessive time of bus movements through the study areas were observed which a stop as a constant value; distance was measured by distance in minutes (measured by bumper-bumper).

Numbers of passengers/students boarding and alighting were observed by a 4-digit tally, which focused on the bus travelling within campus routes. Further analysis used the common standard of Manual 2010, which data observation was taken from GPS measurements $[7,8]$.

\section{Results and Conclusion}

\subsection{Analyze the level of bus service}

Table 4.1. Result analyse the level of bus service.

\begin{tabular}{|c|c|c|c|c|}
\hline $\begin{array}{c}\text { Track } \\
\text { Selection }\end{array}$ & $\begin{array}{l}\text { Average } \\
\text { Time } \\
\text { Travel }\end{array}$ & $\begin{array}{c}\text { Distance } \\
\text { Travel } \\
\text { (meter) }\end{array}$ & $\begin{array}{l}\text { Average } \\
\text { Headway } \\
\text { (minute) }\end{array}$ & $\begin{array}{c}\text { Evaluation } \\
\text { Study by } \\
\text { Area Line, } \\
I_{t, \text { seg }}\end{array}$ \\
\hline $\begin{array}{c}\text { Bus } \\
\text { travelling } \\
\text { in } \\
\text { university } \\
\text { type Etika } \\
\text { Delta } \\
\text { (morning) }\end{array}$ & $\begin{array}{l}15 \text { minute } \\
03 \text { second }\end{array}$ & 5480 & 6 & $\mathrm{C}$ \\
\hline $\begin{array}{c}\text { Bus } \\
\text { travelling } \\
\text { in } \\
\text { university } \\
\text { type Etika } \\
\text { Delta } \\
\text { (evening) }\end{array}$ & $\begin{array}{l}18 \text { minute } \\
15 \text { second }\end{array}$ & 5610 & 7 & $\mathrm{C}$ \\
\hline $\begin{array}{c}\text { Bus } \\
\text { travelling } \\
\text { in } \\
\text { university } \\
\text { type Sikun } \\
\text { Jaya } \\
\text { (morning) }\end{array}$ & $\begin{array}{l}18 \text { minute } \\
28 \text { second }\end{array}$ & 6900 & 8 & B \\
\hline
\end{tabular}

\begin{tabular}{|c|c|c|c|c|}
\hline $\begin{array}{c}\text { Bus } \\
\text { travelling } \\
\text { in }\end{array}$ & & & \\
$\begin{array}{c}\text { university } \\
\text { type Sikun } \\
\text { Jaya } \\
\text { (evening) }\end{array}$ & $\begin{array}{c}35 \text { minute } \\
50 \text { second }\end{array}$ & 6870 & 5 & $\mathrm{D}$ \\
\hline
\end{tabular}

Refer to Table 4.1 the highest ratings is Sikun Jaya movement in the university area in the morning and get assessment score is B while the lowest scoring is movement in the university for Sikun Jaya bus in the evening is $\mathrm{D}$. The average travel time to the time difference can also be seen in turn gives a bad impression on consumers who use the service. Scoring can be seen through the data required and analysed in accordance with the format of the existing formula in the Highway Capacity Manual 2010 (HCM 2010) [9].

\subsection{Analyze the impact of stop on travel time}

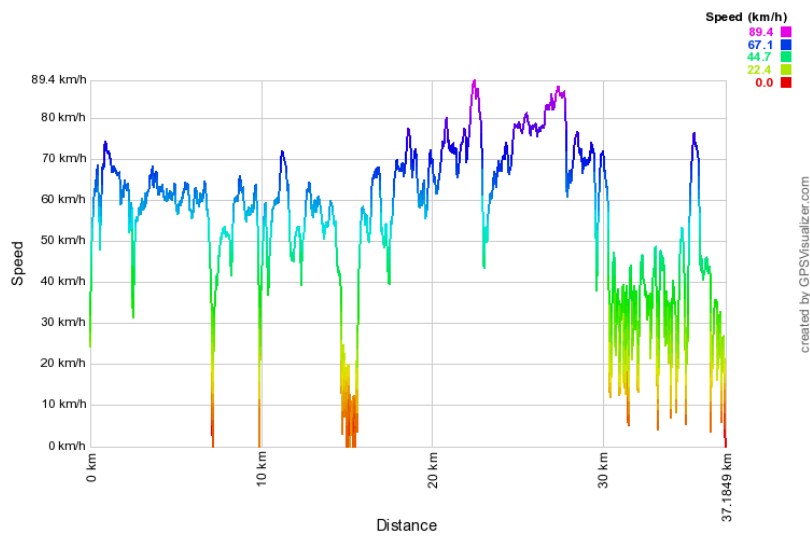

Figure 4. Example graph plotted speed versus time at the morning time

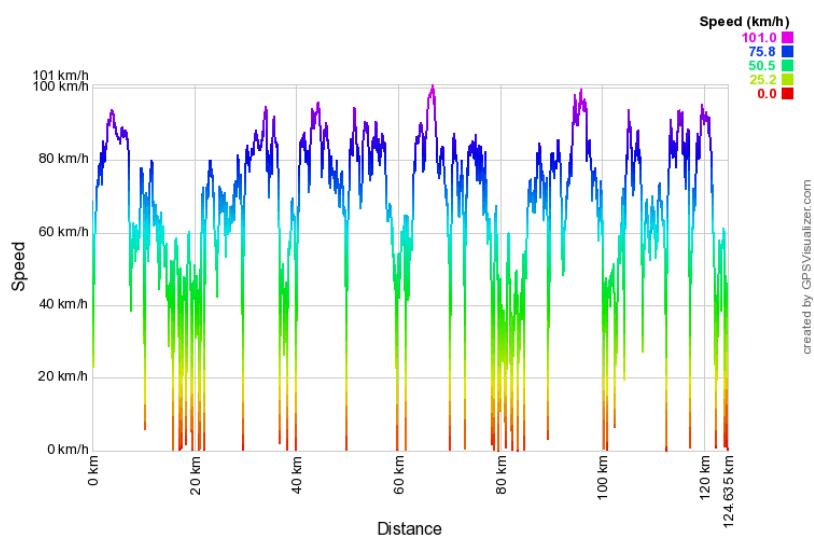

Figure 5. Example graph plotted speed versus time at the evening time

Refer to the figure 4 and figure 5 , there are differences in the pattern of the data speed which is plotted against the distance travelled. There are differences in the speed at 
point 0 because of differences in the volume of traffic is different in the morning and in the evening there are differences cause velocity of $0 \mathrm{~km} / \mathrm{h}$. there was also a difference that can be seen is the travel time taken by the travel time of a trip in the morning and evening. The average difference in velocity also varies due cause deceleration stops occur every time you want to stop. Figure 4 and figure 5 also were as an example of speed profile against distance from the study measurement.

\subsection{Analyze of potential stop area}

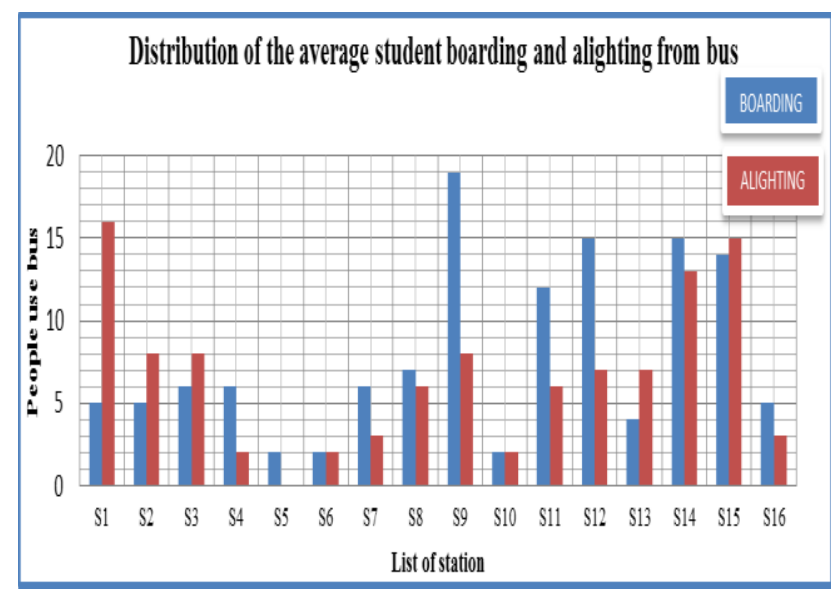

Figure 6. Graph show distribution of the average student

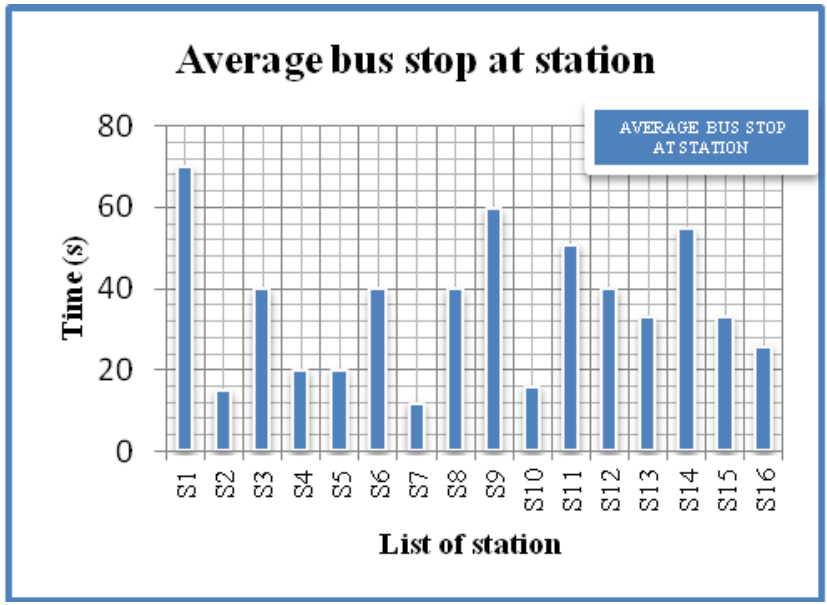

Figure 7. Graph show the average bus stop at the station

Figure 6 shows the average distribution of students boarding and alighting from the bus. This graph shows the frequency of the highest student boarding is at the stop bus in front S9 which is library Tun Aminah. While the distribution alighting is at S14 which is in front of Tun Fatimah College. Besides that, figure 7 shows the average time bus stop at the station. Figure 7 show the highest reading is $\mathrm{S} 1$, which is ATM station.
Table 4.2. Different of road taken by bus and average time travel bus taken each road and time

\begin{tabular}{|c|c|c|c|}
\hline $\begin{array}{c}\text { Travel } \\
\text { Direction }\end{array}$ & $\begin{array}{l}\text { Average } \\
\text { Time } \\
\text { Travel }\end{array}$ & $\begin{array}{l}\text { Distance } \\
\text { (meter) }\end{array}$ & $\begin{array}{c}\text { Average } \\
\text { Speed }(\mathrm{km} / \mathrm{h})\end{array}$ \\
\hline $\begin{array}{c}\text { Perwira } \\
\text { Residential } \\
\text { College } \\
\text { (morning) }\end{array}$ & $\begin{array}{l}17 \text { minute } \\
30 \text { seconds }\end{array}$ & 5610 & 17.83 \\
\hline $\begin{array}{c}\text { Perwira } \\
\text { Residential } \\
\text { College } \\
\text { (evening) } \\
\end{array}$ & $\begin{array}{l}42 \text { minute } \\
50 \text { seconds }\end{array}$ & 5610 & 15.98 \\
\hline $\begin{array}{l}\text { Melewar } \\
\text { Residential } \\
\text { College } \\
\text { (morning) }\end{array}$ & $\begin{array}{l}14 \text { minute } \\
05 \text { seconds }\end{array}$ & 5250 & 23.81 \\
\hline $\begin{array}{c}\text { Melewar } \\
\text { Residential } \\
\text { College } \\
\text { (evening) } \\
\end{array}$ & $\begin{array}{l}\text { 19minute } \\
29 \text { seconds }\end{array}$ & 5250 & 20.15 \\
\hline $\begin{array}{c}\text { Taman } \\
\text { University } \\
\text { Residential } \\
\text { College } \\
\text { (morning) }\end{array}$ & $\begin{array}{l}\text { 37minute } \\
01 \text { seconds }\end{array}$ & 5800 & 24.50 \\
\hline $\begin{array}{c}\text { Taman } \\
\text { University } \\
\text { Residential } \\
\text { College } \\
\text { (evening) }\end{array}$ & $\begin{array}{l}\text { 17minute } \\
30 \text { seconds }\end{array}$ & 5800 & 10.91 \\
\hline $\begin{array}{c}\text { Kelisa } \\
\text { Residential } \\
\text { College } \\
\text { (morning) } \\
\end{array}$ & $\begin{array}{l}\text { 17minute } \\
30 \text { seconds }\end{array}$ & 9670 & 29.14 \\
\hline $\begin{array}{c}\text { Kelisa } \\
\text { Residential } \\
\text { College } \\
\text { (evening) } \\
\end{array}$ & $\begin{array}{l}\text { 17minute } \\
\text { 30seconds }\end{array}$ & 9680 & 17.52 \\
\hline $\begin{array}{l}\text { Etika Delta } \\
\text { bus activity in } \\
\text { campus } \\
\text { (morning) }\end{array}$ & $\begin{array}{l}\text { 17minute } \\
30 \text { seconds }\end{array}$ & 5480 & 20.41 \\
\hline $\begin{array}{c}\text { Etika Delta } \\
\text { bus activity in } \\
\text { campus } \\
\text { (evening) }\end{array}$ & $\begin{array}{l}17 \text { minute } \\
30 \text { seconds }\end{array}$ & 5610 & 17.38 \\
\hline $\begin{array}{c}\text { Sikun Jaya } \\
\text { bus activity in } \\
\text { campus } \\
\text { (morning) }\end{array}$ & $\begin{array}{l}\text { 17minute } \\
30 \text { seconds }\end{array}$ & 6900 & 18.15 \\
\hline $\begin{array}{c}\text { Sikun Jaya } \\
\text { bus activity in } \\
\text { campus } \\
\text { (evening) }\end{array}$ & $\begin{array}{l}\text { 17minute } \\
30 \text { seconds }\end{array}$ & 6800 & 11.16 \\
\hline
\end{tabular}

\section{Conclusions}

The following study found that results of the current existing bus services that should be improved in the university area or changed to an alternatives type of buses [10] because these services are often used by students who do not have their own vehicles to travel. It also the main transit for students/passengers to travel from campus to outside places. The study also found the 
locations of bus stops that provide the potential for students to use this service. The results also shows that stop area used by students should further extend the service because the bus ride would be faster and more efficient because of less waiting time at the stop and also shorter the journey time to complete a cycle. In addition, it shows that bus services should be improved and provides convenience bus stops for a comfortable which can accommodate a large number of students.

The bus facilities provide huge impact on student's comfort because it may reduces the feeling such a long wait that may not satisfy the students/passengers. The final objective is to study the effect of the number of stops on the time travel. The results of this study demonstrate the effect on number of stops that and travel time by linking the greater number of stops made by a longer bus time travel to complete a full circle. In addition, the results of this study may also explain the existing volume of bus traffic and it can be used to predict expectedly travel time accurately.

\section{Acknowledgement}

The authors thank to the Universiti Tun Hussein Onn Malaysia for supporting the study through U395 contract grant. Appreciations are also presented to the Smart Driving Research Center, Faculty of Civil and Environmental Engineering and Registrar Office Universiti Tun Hussein Onn Malaysia for facilitating the study and make possible the results to be published.

\section{References}

1. Ambak, K., Kasvar, K. K., Daniel, B. D., Prasetijo, J., Ghani, A. R. A., MATEC Web of Conf. 47, 03008 (2016)

2. Public Transportation Fact Book, $63^{\text {rd }}$ Edition. American Public Transport Association (2012)

3. HEPA, Pelan UTHM. Dec 3, https://www.uthm.edu.my/HEPA (2014)

4. Ruslawati A. W., Muhamad N.B., Riza Atiq A. O. K. R., Jurnal Teknologi (Sciences \& Engineering) 78(2): 157-163 (2016)

5. P. Bullock, Journal of Public Transportation, no 1. (vol8), ms21-40 (2005)

6. Aimee Flannery, First Edition, New Fettern Lane, London: Spon Press (2010)

7. Prasetijo, J. \& Zainal, Z. F., MATEC Web of Conf. 47, 03001 (2016)

8. GPS Online, GPS Online tracks Sydney buses: 1 Sept (2000)

9. P. Reus, HCM 2010 First Edition, Sydern Denmark:Spon Press, California and Ostorn Engineeting (2010)

10. Azhar Yusof, Bas Elektrik Mulakan Operasi. Melaka Hari Ini.4-5 (2014) 